\title{
The Impact of Land Transfer on Farmer's Entrepreneurship
}

\author{
Huang Nuoxin ${ }^{1}$, Niu Ziyao ${ }^{2 *}$ \\ ${ }^{1}$ Department of Research Institute of Economics and Management, South Western University of Finance and \\ Economics, Chengdu, China \\ ${ }^{2}$ Department of Majoring in Economics, Northeastern University, Shenyang, Liaoning, China \\ *niuziyao0826@163.com
}

\begin{abstract}
Entrepreneurship is a critical way for rural residents to achieve high-quality employment and increase farmers' income. Based on a sample of 12,771 rural households from China Family Panel Studies in 2018, this paper constructs a binary Logit model to explore the relationship between land transfer and farmers' entrepreneurship. And then examine the mechanism effect of credit constraints and the heterogeneous role of risk preferences. This study draws the following conclusions: Firstly, the land transfer out can significantly affect farmers' entrepreneurship, while land transfer in cannot. Secondly, the land transfer can promote farmers' entrepreneurship by alleviating credit constraints. Third, land transfer promotes entrepreneurship among farmers with stronger risk preferences. With these findings, this paper puts forward some suggestions: develop a market for the transfer of rural land management rights, and increase the transfer ratio; encourage farmers to participate in land transfer actively; and expand financing channels to support entrepreneurship among agricultural labour.
\end{abstract}

Keywords: Land transfer, Land transfer out, Farmers' entrepreneurship, Credit constraints, Risk references.

\section{INTRODUCTION}

Entrepreneurship has emerged as a vital form of employment in China with the deepening of reform and opening up and the coordinated development of urbanrural interaction [4]. For rural residents, peasant entrepreneurship refers to peasant households engaging in non-agricultural self-employment, specifically starting up farming, breeding, processing industries, catering services, joining cooperatives, etc. Farmers' entrepreneurship can promote labour migration, narrow the urban-rural gap, and add momentum to the development of the rural economy [5]. By the end of 2019, rural private enterprises and self-employment reached 82.67 million and 60 million people, respectively, increasing $11.4 \%$ and $6.7 \%$ compared to 2018 . Those employed absorbed a total of $49.6 \%$ of rural employment. Moreover, the land is a key resource for farmers. The land transfer has promoted non-farm employment of rural labour to some extent, optimizing the employment structure and contributing to the revitalization of the countryside. According to data from China's Ministry of Agriculture and Rural Affairs, by the end of 2019, 556 million mu of land had been transferred from family households, and the number of farming households that had transferred their contracted land reached 73.21 million.

The transfer of land to farmers continues to influence their entrepreneurial behaviour. On the one hand, an increase in land transfer has raised income from nonagricultural work and accumulated initial capital for farmers to start their businesses [1]. At the same time, land, as a collateral asset, helps farmers to ease their credit constraints and thus obtain more capital for entrepreneurship. On the other hand, the land is the most basic means of subsistence for farmers and guarantees farmers' wellbeings. Risk-averse farmers are reluctant to invest their extra capital in entrepreneurship, even if they have increased their income through land transfer. In this context, can land transfer promote entrepreneurship among farmers? Is there a significant difference in the impact of the land transfer on entrepreneurship among farmers with different risk preferences? Through what mechanisms does land transfer promote entrepreneurship? Answering these questions is essential for promoting mass entrepreneurship and innovation. 
Based on the above objectives, this paper uses data from China Family Panel Studies(CFPS) in 2018 to develop a binary logit model and examine the impact of the land transfer on farm household entrepreneurship. Furthermore, the paper introduces credit constraints to explore their mechanism effect between land transfer and rural household entrepreneurship. Lastly, the paper analyses the heterogeneity between farm household entrepreneurial decisions with different risk preferences. Three main factors, personal, household and social environment characteristics of farmers, are taken into account.

\section{LITERATURE REVIEW}

Under the new economic standard, farming entrepreneurship provides an opportunity to relieve the pressure on farmers' employment, increase their productivity and income, and narrow the gap between urban and rural areas [17]. There are many types of research about the factors that influence farmers' entrepreneurship, and those studies can be divided into individual factors, family factors, and social and environmental factors. In terms of individual factors, the existing literature mainly analyzed individuals' age, gender, health status, and education level [3]. In terms of family factors, they mainly focused on household income and family members [12]. The main focus is on economic [8], political, and cultural [14] in a social context. It is shown that both farmers' conditions and proper social context are required for entrepreneurship.

The 'separation of three rights' under China's land ownership system means that farmers have the right to contract for land and the right to dispose of land management rights. This policy greatly improves the efficiency of land transfer and the realization of farmers' contractual rights. Existing literature has examined the impact of the land transfer on farmers' entrepreneurship in the following areas. First, the land transfer out can free up family agricultural labour and increase the proportion of family members in non-farm employment [16]. Farmers are embedded in social and industrial networks during the process, which helps them perceive, identify and seize entrepreneurial opportunities to implement their entrepreneurial plans.

Hypothesis 1: Land transfer out can influence farm entrepreneurship.

Secondly, the land transfer in can meet the demand for land for entrepreneurship and stimulate farmers with skills and capital to start their businesses. That will promote various types of new agricultural business subjects such as large professional households, family farms, farmers' cooperatives and leading agricultural industrialized enterprises [2].

Hypothesis 2: land transfer in can influence farmers' entrepreneurship.
Third, the land transfer is conducive to easing credit constraints on farmers, thereby influencing their entrepreneurship. The land is good collateral. So farmers can use their legally acquired land management rights as collateral to obtain loans, solve the financing problem, and raise initial capital for entrepreneurship [11].

Hypothesis 3: land transfer influences farm entrepreneurship through the mechanism of credit constraints.

Fourth, different risk preferences of farmers influence entrepreneurial decisions [9]. Since entrepreneurship is a high-risk activity, risk tolerance is an essential factor influencing entrepreneurial behaviour [15]. Based on a Swedish administrative database, Hvide [10] found that people with higher risk tolerance are more likely to start a business.

Hypothesis 4: Risk preferences play a heterogeneous role in the impact of the land transfer on farmers' entrepreneurship.

\section{STUDY DESIGN}

\subsection{Data sources}

This paper uses data from the 2018 China Family Panel Studies(CFPS). The database was released by the Institute of Social Science Survey Centre(ISSS) of Peking University, covering 16,000 households in 25 provinces and autonomous regions of China. The research was conducted five times respectively in 2010, 2012, 2014, 2016 and 2018, with the survey divided into three levels: individual, household and community. This paper focuses on the impact of the land transfer on farmers' entrepreneurship. In order to make the sample more representative, non-farm households and data with missing values are excluded. Some variables were logarithmically selected. Finally, a valid sample of 12,771 data was retained after filtering out those with contracted land in rural areas and over 18 years old.

\subsection{Selection of variables}

\section{Explained variables}

The entrepreneurship variable was defined as a discrete binary variable. Apply the question in the CFPS2018 questionnaire "In the past 12 months, has any member of the household been self-employed or started a private business?" to determine whether or not the farmer has started a business. If the answer is yes, the household has started a business, assigned a value of 1 . The opposite is assigned a value of 0 .

\section{Core explanatory variables}

The core explanatory variables include land transfer in and land transfer out. 
The land transfer in the variable is based on the question from the CFPS2018 questionnaire "In the past 12 months, how much did the household pay in rent for land leased from individuals or collectives?". The value is taken as a logarithm.

The land transfer out variable is based on the question in the CFPS2018 questionnaire "In the past 12 months, how much did the household receive for renting out the land allocated to someone collectively?". The value is taken as a logarithm.

\section{Control variables}

Based on the research of previous scholars, this paper introduces the characteristics of individuals, family and social environment. Individual characteristics include gender, age, marriage, health status and education level. Household characteristics include family size, total household income, and total household consumption expenditure. Social environment characteristics mainly consider social security factors, including whether the household has at least one type of pension insurance.

Table 1 Description of variables

\begin{tabular}{|c|c|}
\hline $\begin{array}{l}\text { Variable } \\
\text { name }\end{array}$ & Description \\
\hline fm & $\begin{array}{l}\text { In the past } 12 \text { months, has any family } \\
\text { member been self-employed or run a } \\
\text { private business: No=0, Yes }=1\end{array}$ \\
\hline fieldin & Logarithmic treatment of rent paid \\
\hline fieldout & $\begin{array}{l}\text { Rental charges are processed } \\
\text { logarithmically }\end{array}$ \\
\hline age & Year \\
\hline gender & Female $=0$, Male $=1$ \\
\hline marriage & Single $=0$, Married $=1$ \\
\hline health & $\begin{array}{l}\text { Health self-assessment: unhealthy }=1 \text {, } \\
\text { fair }=2 \text {, relatively healthy=3, very } \\
\text { healthy=4, very healthy=5 }\end{array}$ \\
\hline family-size & $\begin{array}{l}\text { Total number of people in the household } \\
\text { (digits) }\end{array}$ \\
\hline $\operatorname{lnfin}$ & The logarithm of total household income \\
\hline $\ln \exp$ & $\begin{array}{l}\text { The logarithm of total household } \\
\text { expenditure }\end{array}$ \\
\hline qi & $\mathrm{No}=0, \mathrm{Yes}=1$ \\
\hline $\begin{array}{c}\text { Risk } \\
\text { Appetite }\end{array}$ & Assign a value of 1 \\
\hline $\begin{array}{l}\text { No risk } \\
\text { appetite }\end{array}$ & Assign a value of 0 \\
\hline debt & No $=0$, Yes $=1$ \\
\hline
\end{tabular}

\subsection{Model construction}

This paper applies China's data in 2018 to estimate the direct effect of land transfer on entrepreneurial choice, using farmers' entrepreneurial decisions as to the explanatory variable and land transfer in and out as the core explanatory variables. The entrepreneurial decision is set as a binary variable. A logit regression model is constructed, and the models are as follows.
$P(f m=1)=F\left(\beta_{0}+\beta_{1}\right.$ fieldout $+\beta_{2}$ age $+\beta_{3}$ gender $+\beta_{4}$ marriage $+\beta_{5}$ health $+\beta_{6}$ familysize $+\beta_{7} \operatorname{lnfin}+\beta_{8} \ln \exp +\beta_{9}$ qi $)(1)$ $P(f m=1)=F\left(\beta_{0}+\beta_{1}\right.$ fieldin $+\beta_{2}$ age $+\beta_{3}$ gender $+\beta_{4}$ marriage

$+\beta_{5}$ health $+\beta_{6}$ familysize $+\beta_{7}$ lnfin $+\beta_{8} \ln \exp +\beta_{9}$ qi $)(2)$

Where fm represents the entrepreneurial decision, fieldout represents the land transfer-out variable, field-in represents the land transfer-in variable, and $\beta_{\mathrm{i}}$ is a constant. The other variables are control variables that affect entrepreneurship.

\section{EMPIRICAL RESULTS AND ANALYSIS}

\subsection{The impact of the land transfer on farmers' entrepreneurship}

The effects of land transfer in and land transfer out on farmers' entrepreneurship are shown separately in Table 2 , and cluster robust standard errors are applied. The results show that land transfer in does not significantly affect farmer entrepreneurship, while land transfer out positively affects farmer entrepreneurship at the $1 \%$ level of significance. Therefore Hypothesis 1 of this paper is valid, while Hypothesis 2 is not. It may be because farmers can increase their income by renting out their land and accumulating initial capital for entrepreneurship. As for the land transfer in, however, it is still dominated by the transfer of small lands in China, which will only lead to a gradually expanding area under self-cultivation. That further increases the probability of farmers' participation in agricultural work and then inhibits their entrepreneurial behaviour to a certain extent. Moreover, the characteristics of scattered land in China make it difficult for land transfer to form a scale effect. Hence farmers can only receive limited revenues and lose faith in entrepreneurship.

Table 2 Impact of land transfer on farmers' entrepreneurship

\begin{tabular}{|l|l|l|}
\hline Variable name & Return to baseline & Return to baseline \\
\hline \multirow{2}{*}{ fieldin } & -0.001 & \\
& $(0.017)$ & \\
\hline \multirow{2}{*}{ fieldout } & & $0.048^{* * *}$ \\
& & $(0.013)$ \\
\hline \multirow{2}{*}{ age } & $-0.010^{* * *}$ & $-0.011^{* * *}$ \\
& $(0.003)$ & $(0.003)$ \\
\hline \multirow{2}{*}{ gender } & 0.071 & 0.068 \\
& $(0.062)$ & $(0.062)$ \\
\hline \multirow{2}{*}{ marriage } & $0.587 * * *$ & $0.578^{* * *}$ \\
& $(0.134)$ & $(0.134)$ \\
\hline \multirow{2}{*}{ health } & 0.016 & 0.017 \\
& $(0.026)$ & $(0.026)$ \\
\hline \multirow{2}{*}{ familysize } & $0.093 * * *$ & $0.090^{* * *}$ \\
& $(0.015)$ & $(0.150)$ \\
\hline \multirow{2}{*}{ lnfin } & $0.496^{* * *}$ & $0.496 * * *$ \\
& $(0.045)$ & $(0.045)$ \\
\hline \multirow{2}{*}{ lnexp } & $0.376^{* * *}$ & $0.380^{* * *}$ \\
& $(0.044)$ & $(0.044)$ \\
\hline \multirow{2}{*}{ qi } & $-0.300^{* * *}$ & $-0.297 * * *$ \\
\hline \multicolumn{2}{|l|}{ Note: * $* *$ and $* * *$ indicate significant at the $10 \%, 5 \%$ and } \\
1\% levels respectively. & $(0.101)$ \\
\hline
\end{tabular}




\subsection{Mechanism analysis}

Potential entrepreneurs are faced with the dilemma of financing constraints. This paper examines the mechanism of credit constraints. First, land transfer out is positively influential on farmer entrepreneurship at the $1 \%$ level of significance. Then, land transfer out can positively affect credit constraints at the $10 \%$ level of significance. It indicates that land transfer out increases farmers' income, while land as a collateralizable property relaxes their credit constraints. Finally, according to past studies, credit constraints have a negative effect on farmer entrepreneurship [6]. The capital accumulation process is relatively short for farmers today, and they face financial burdens such as children's education and supporting the elderly. Capital constraints are often more common and severe for them [13]. If farmers' savings are difficult to fill the entrepreneurship gap, they will not choose to start a business [7].

Therefore, Hypothesis 3 of this paper is valid: credit constraint acts as a mechanism to influence the effect of land transfer on farmers' entrepreneurship.

Table 3 Mechanism analysis

\begin{tabular}{|l|l|l|}
\hline $\begin{array}{l}\text { Variable } \\
\text { name }\end{array}$ & $\begin{array}{l}\text { Dependent variable: } \\
\text { Farmer } \\
\text { entrepreneurship }\end{array}$ & $\begin{array}{l}\text { Dependent } \\
\text { variable: credit } \\
\text { constraints }\end{array}$ \\
\hline fieldout & $\begin{array}{l}0.048^{* * *} \\
(0.013)\end{array}$ & $\begin{array}{l}0.019 * \\
(0.011)\end{array}$ \\
\hline age & $\begin{array}{l}-0.011 * * * \\
(0.003)\end{array}$ & $\begin{array}{l}-0.020 * * * \\
(0.002)\end{array}$ \\
\hline gender & $\begin{array}{l}0.068 \\
(0.062)\end{array}$ & $\begin{array}{l}0.140 * * \\
(0.047)\end{array}$ \\
\hline marriage & $\begin{array}{l}0.578 * * * \\
(0.134)\end{array}$ & $\begin{array}{l}-0.019 \\
(0.087)\end{array}$ \\
\hline health & $\begin{array}{l}0.017 \\
(0.026)\end{array}$ & $\begin{array}{l}-0.159 * * * \\
(0.020)\end{array}$ \\
\hline familysize & $\begin{array}{l}0.090 * * * \\
(0.150)\end{array}$ & $\begin{array}{l}0.146 * * * \\
(0.012)\end{array}$ \\
\hline lnfin & $\begin{array}{l}0.496 * * * \\
(0.045)\end{array}$ & $\begin{array}{l}-0.275 * * * \\
(0.030)\end{array}$ \\
\hline lnexp & $\begin{array}{l}0.380 * * * \\
(0.044)\end{array}$ & $\begin{array}{l}0.378 * * * \\
(0.035)\end{array}$ \\
\hline qi & $\begin{array}{l}-0.297 * * * \\
(0.101)\end{array}$ & $\begin{array}{l}-0.365 * * * \\
(0.075)\end{array}$ \\
\hline
\end{tabular}

Note: $* * *$ and $* * *$ indicate significant at the $10 \%, 5 \%$ and $1 \%$ levels respectively.

\subsection{Heterogeneity analysis}

This paper explores the role of heterogeneity in the impact of land transfer on farm household entrepreneurship from risk preferences. Cluster robust standard errors are applied. The heterogeneity test is shown in the table. Among them, 1,087 farmers had no risk preference, and 8,647 farmers had risk preference. According to the test, land transfer positively affects the entrepreneurial choice at the $1 \%$ level of significance for risk-loving farmers, while land transfer does not significantly affect entrepreneurship among risk-averse farmers. The results reveal that if farmers are risk averse, they will not start their own business even with sufficient income and relaxation of credit constraints. Hypothesis 4 of this paper holds: risk preference has a heterogeneous role in the effect of land transfer on farm household entrepreneurship.

Table 4 Heterogeneity analysis

\begin{tabular}{|l|l|l|}
\hline Variable name & No risk appetite & Risk-averse \\
\hline \multirow{2}{*}{ fieldout } & 0.049 & $0.047 * * *$ \\
& $(0.048)$ & $(0.016)$ \\
\hline \multirow{2}{*}{ age } & -0.010 & $-0.011^{* * *}$ \\
& $(0.010)$ & $(0.003)$ \\
\hline \multirow{2}{*}{ gender } & 0.149 & $0.160^{* *}$ \\
& $(0.212)$ & $(0.076)$ \\
\hline \multirow{2}{*}{ marriage } & 0.506 & $0.687 * * *$ \\
& $(0.406)$ & $(0.194)$ \\
\hline \multirow{2}{*}{ health } & -0.012 & 0.030 \\
& $(0.092)$ & $(0.033)$ \\
\hline \multirow{2}{*}{ familysize } & 0.051 & $0.111 *$ \\
& $(0.054)$ & $(0.019)$ \\
\hline \multirow{2}{*}{ lnfin } & $0.660 * * *$ & $0.395 * * *$ \\
& $(0.160)$ & $(0.051)$ \\
\hline \multirow{2}{*}{ lnexp } & $0.460 * * *$ & $0.393 * * *$ \\
& $(0.157)$ & $(0.053)$ \\
\hline \multirow{2}{*}{ qi } & 0.039 & $-0.318^{* * *}$ \\
\hline $\mathrm{N}$ & $(0.367)$ & $(0.118)$ \\
\hline
\end{tabular}

Note: $*, * *$ and $* * *$ indicate significant at the $10 \%, 5 \%$ and $1 \%$ levels respectively.

\section{CONCLUSION}

Using CFPS 2018 data and a logit model, this paper empirically tests the entrepreneurial effect of land transfer. It puts forward the following conclusions and policy recommendations: Firstly, the land transfer out can significantly affect farming households' entrepreneurship, while land transfer in cannot. Therefore, the right to operate rural land should be released and stabilized. The land transferring market should be continuously cultivated to increase the transfer ratio and provide a good market environment for farmers to transfer their land. Second, the land transfer can promote entrepreneurship among farmers by easing credit constraints. Thus, financing channels should be expanded to ensure that informal financing supports entrepreneurship among agricultural migrants. Financial institutions need to design differentiated loan products to meet the diverse needs of agricultural migrants and increase the participation of farmers in loans from formal financial institutions. Third, the land transfer will promote entrepreneurship among farmers with a substantial risk appetite. Therefore, policies should focus on enhancing the personal quality of the agricultural transfer workforce and improving their ability to cope with risks.

\section{REFERENCES}

[1] Arum, R. and W. Mueller, 2004, The Reemergence of Self-employment: A Comparative Study of Self- 
employment Dynamics and Social Inequality, Princeton University Pree

[2] Chamberlin, J., and J. Ricker-Gilbert, 2016, Participation in Rural Land Rental Markets in SubSaharan Africa: Who Benefits and by How much? Evidence from Malawi and Zambia, American Journal of Agricultural Economics, 98(5):15071528.

[3] Davidsson, P. and Honig, B., 2003, The Role of Social and Human Capital among Nascent Entrepreneurs, Journal of Business Verturing, 18(3): 301-331

[4] Djankov, S., Y.Y Qian, G. Roland, and E. Zhuravskaya, 2006, Who Are China's Entrepreneurs?

[5] Falkinger, J., and V. Grossmann, 2013, Oligarchic Land Ownership, Entrepreneurship and Economic Development, Journal of Development Economics, 101(1):206-215

[6] Freire Gibb, L. C., Nielsen, K. Entrepreneurship Within Urban and Rural Areas: Creative People and Social Networks. Regional Stud- ies, 2014, 48(1), $139 \sim 153$

[7] Gentry, W. M., \& Hubbard, R. G. Entrepreneurship and Household Saving. Advances in Economic Analysis \& Policy, 2004, 4(1), 1 57

[8] Heim, B. T., and I. Z. Lurie, 2010, The effect of selfemployed health insurance subsides on selfemployment, Journal of Public Economics, 94(11): 995- 1007

[9] Hu, F., 2014, Risk Attitudes and Self-employment in China, China \& World Economy, 22(3): 101-120.

[10] Hvide, Hans K., and G. Panos, 2014, Risk tolerance and entrepreneurship, Journal of Financial Economics, 111(1): 200-223

[11] Kaika, M., and L. Ruggiero, 2016, Land Financialization as a Lived Process: The Transformation of Milan's Bicocca by Pirelli, European Urban and Regional Studies, 23(1):3-22.

[12] Lin, Song, Si,Steven, 2014, Factors affecting peasant entrepreneurs' intention in the Chinese context[J].International entrepreneurship and management journal, 10(4):803-825

[13] Peter F. Korsching, Peter, G., Hunger, J. D. Founder Motivation and Community Context Interaction in Entrepreneurship for Small City Smart Growth. Proceedings of the 14th Conference on the Small City and Regional Community, 2001, September (28-29), 347 358

[14] Siqueira, A.C.O., 2007, Entrepreneurship and Ethnicity: the Role of Human Capital and Family
Social Capital, Journal of Developmental Entrepreneurship, 12(01): 31-46

[15] Van Pragg, C. M., and J. S. Cramer, 2001, The roots of entrepreneurship and labour demand: individual ability and low risk aversion, Economica, 68(269): $45-62$

[16] Willmore, L., G. Y. Cao, and L. J. Xin, 2012, Determinants of Off-Farm Work and Temporary Migration in China, Population and Environment, 33(2): 161-85 C. Cao, and L. J. Xin, 2012, Determinants of Off-Farm Work and Temporary Migration in China, Population and Environment, 33(2): 161-85

[17] Yang Z., Xuejin L., 2017, Cognitive Ability and Family Entrepreneurship -- an Empirical Analysis Based on Chinese Family Panel Studies data, Economic Trends, 02: 66-75 